\title{
Preparation of Cu Nanocomposites from EDA, DETA, and Jeffamine Cored PAMAM Dendrimers with TRIS and Carboxyl Surface Functional Groups
}

\author{
Ali Serol Ertürk, ${ }^{1} *$ Mustafa Ulvi Gürbüz, ${ }^{2}$ Metin Tülï \\ and Abdürrezzak Emin Bozdoğan² \\ ${ }^{1}$ Department of Basic Pharmaceutical Sciences, Faculty of Pharmacy, Adiyaman University, 02040, Adiyaman, Turkey \\ ${ }^{2}$ Department of Chemistry, Y1 ldiz Technical University, 34210, Istanbul, Turkey \\ * Corresponding author: E-mail: aserturk@adiyaman.edu.tr \\ $\mathrm{Tel}+90$ (416) 2233800 /2808; fax +90 (416) 2233809
}

Received: 19-04-2016

\begin{abstract}
This study presents the synthesis and UV-Vis characterization of $\mathrm{Cu}$ nanocomposites from ethylenediamine (EDA) (E), diethylenetriamine (DETA) (D), and Jeffamine ${ }^{\circledR}$ T-403 (P) cored PAMAM dendrimers (PAMAMs) with TRIS and carboxyl surface functional groups. Cu-PAMAM dendrimer encapsulated nanoparticles (Cu-DENs) were characterized by UV-Vis spectroscopy. Disappearance of the $680 \mathrm{~nm} d-d$ transition and 270-300 $\mathrm{nm}$ ligand to metal charge transfer (LMCT) peaks and the formation of monotically increasing exponential band were used as the evidence of the successful synthesis of $\mathrm{Cu}$-DENs in addition to immediate color change of dendrimer-metal mixture solutions from blue to golden brown by reduction. Synthesized Cu-DENs could be facilitated as novel alternatives to the existing nanomaterials used in a wide range of applications involving bio and chemical sensors, catalysis, hydrogenations, oxidations, semiconductors, noble metals, magnetic dendrimer nanocomposites, environmental cleanup and many others.
\end{abstract}

Keywords: TRIS and carboxyl terminated PAMAM dendrimers; Dendrimer encapsulated nanoparticles; EDA, DETA, Jeffamine, $\mathrm{Cu}$ nanocomposites

\section{Introduction}

Dendrimers are a new class of polymeric materials and cascade molecules with their spherical three-dimensional (3D) morphology, typically symmetric around a core. There has been a growing interest toward dendrimers due to their controllable structures, globular shapes and definite monodisperse nanosizes. ${ }^{1}$ In particular, controllable synthesis of dendrimers allows them to be architecturally designed with the desired physical and chemical properties for the desired applications. ${ }^{2}$ Design variables of dendrimers are a core, repeating branches emanating from the core, and surface-groups. Selectivity on these variables makes dendrimers proper host and candidate for guest molecules so that various metal nanoparticles have been successfully stabilized using dendrimers as templates with tunable solubility and surface reactivity. ${ }^{3}$
Dendrimer encapsulated nanoparticles (DENs) are used as templates to control size, stability and solubility of nanoparticles in the range of $1 \mathrm{~nm}$ to up to $4-5 \mathrm{~nm} .^{4}$ Crooks et al. ${ }^{4}$ announced dendrimers as good hosting metal nanoparticles because of their uniform structures leading to well-defined nanoparticles, availability to participate in catalytic reactions, resistance to agglomeration, and selectivity to control encapsulation of small substrate molecules.

DENs have gained great interest in the field of chemical sensors in molecular recognition, ${ }^{5}$ biochemistry, catalysis, ${ }^{6,7}$ optoelectronics, ${ }^{8}$ application areas of semiconductors, noble metals, magnetic dendrimer nanocomposites, and environmental cleanup. ${ }^{9}$ First DENs were reported by Crooks et al. ${ }^{10}$ and followed parallel by Tomalia. ${ }^{9}$ Different types of $\mathrm{Pt}, \mathrm{Pd}, \mathrm{Au}, \mathrm{Ag}, \mathrm{Cu}, \mathrm{Ni}, \mathrm{Ru}, \mathrm{Mn}$, and Fe DEN$\mathrm{s}$ were prepared in the literature ${ }^{4,11-15}$ by using dendrimers with amine, carboxyl, and hydroxyl surface-groups. ${ }^{16-21}$ 
Modification of surface-groups of dendrimers is an important process to gain the desired solubility. TRIS is the abbreviation of the common known organic compound, tris(hydroxymethyl) aminomethane, with the chemical formula of $\left(\mathrm{HOCH}_{2}\right)_{3} \mathrm{CNH}_{2}$. It is widely used in biochemistry, molecular biology, and is highly water-soluble. Surface modified dendrimers with TRIS are highly water soluble. ${ }^{22}$ In our recent study, we have shown the microwave-assisted fast, facile and one-pot synthesis of a series of TRIS-terminated poly(amidoamine) PAMAM (PAMAM-TRIS) dendrimers with ethylenediamine (E), diethylenetriamine (D), and Jeffamine (P) core. ${ }^{23}$ Here, we have introduced the synthesis of generation-3 (G3) and -4 (G4) E, D, and P cored PAMAM dendrimers (PAMAMs) with TRIS and carboxyl end groups, and later used these templates for the preparation of $\mathrm{Cu}$ nanocomposites. Indeed, this study is the first study presenting the synthesis and UV-Vis characterization of G3 and G4, D and $\mathrm{P}$ cored PAMAM-COOH dendrimers templates, and $\mathrm{Cu}$-PAMAM-TRIS and $\mathrm{Cu}$-PAMAM-COOH nanocomposites. Synthesized $\mathrm{Cu}$-DENs can take a potential use in the future studies with a wide range of applications.

\section{Experimental}

\section{1. Materials and Apparatus}

Jeffamine ${ }^{\circledR}$ T403 Mn 440, diethylenetriamine (DETA), methyl acrylate, ethylenediamine (EDA), methanol, n-butanol, tris(hydroxymethyl) aminomethane (TRIS), $\mathrm{NaOH}, 37 \% \mathrm{HCl}, \mathrm{NaH}_{2} \mathrm{PO}_{4}, \mathrm{NaCl}$, potassium hydrogen phthalate (KHP), $\mathrm{CuSO}_{4} .5 \mathrm{H}_{2} \mathrm{O}$, and $\mathrm{NaBH}_{4}$, were supplied from Merck. All solutions were prepared by 18.2 $\mathrm{M} \Omega$ Millipore Milli-Q deionized water. $\mathrm{NaOH}$ solutions were used as titrant after standardized with a primary grade KHP. Standardized $\mathrm{HCl}$ against KHP was used as excess acid in order to adjust initial $\mathrm{pH}$ of dendrimer solutions. Dendrimer solutions were stored at $4{ }^{\circ} \mathrm{C}$. Unless otherwise stated all the chemicals were in analytical grade and used without further purification.

Spectroscopic titrations were carried out automatically by using TitroLine ${ }^{\circledR} 7000$ (SI Analytics GmbH, Hattenbergstraße, Germany) autotitrator equipped with thermostated titration vessel under nitrogen media and PG TG 70 UV-Vis spectrophotometer equipped with UVWin5 Software v5.0.5.

\section{2. Synthesis of PAMAMs}

PAMAM-TRIS (Cn.TRIS) dendrimers were synthesized according to our recent study. ${ }^{23} \mathrm{C}$ refers to dendrimer core, which are ethylenediamine (E), dietilentriamine (D), and Jeffamine (P) while $\mathrm{n}$ is the generation number. PAMAM-COOH dendrimers $(\mathrm{Cn} . \mathrm{COOH})$ were prepared by the slight modification of literature procedure ${ }^{24}$ and our previous study. ${ }^{25}$ During the synthesis of PAMAM-
$\mathrm{COOH}$ dendrimers, briefly, a methanolic solution of esterterminated PAMAM dendrimers (PAMAM- $\left.\mathrm{OCH}_{3}\right)$ (Cn.5) dendrimers was mixed with $1.5 \mathrm{M}$ equiv. of $\mathrm{NaOH}$ per terminal ester. The final mixture was stirred for $24 \mathrm{~h}$. Excess amount of solvent was removed under vacuum at bath temperature $65{ }^{\circ} \mathrm{C}$. The remaining oil was dissolved in methanol and again evaporated in vacuo. Drying under vacuum resulted in a white powder product. Yields were $100 \%$. The detailed experimental, characterization data were given in the supporting information (Table S1). Synthesized G3-G4 E, D and P cored PAMAM-COOH, and PAMAM-TRIS dendrimers were used for the preparation of dendrimer encapsulated $\mathrm{Cu}$ nanomaterials $(\mathrm{Cu}-$ DENs).

\section{3. Spectroscopic Titrations of PAMAMs with $\mathrm{Cu}^{2+}$ Ions and Synthesis of $\mathrm{Cu}(\mathrm{II})$-PAMAM Dendrimer Complexes}

The maximum number of $\mathrm{Cu}^{2+}$ ions, PAMAMs can complex and to be used in the synthesis of Cu-DENs, were determined via spectroscopic titrations. We have shown the microwave-assisted synthesis, characterization and $\mathrm{Cu}(\mathrm{II})$ intra-dendrimer complexes of $\mathrm{E}, \mathrm{D}$, and $\mathrm{P}$ cored G3, G4 PAMAM-TRIS dendrimers in our recent study. ${ }^{23}$ By using the same procedure, we have performed the spectroscopic titrations of E, D, and P cored G3, G4 PAMAM-COOH dendrimers and their $\mathrm{Cu}(\mathrm{II})$ complexes. Concentrations used to titrate aqueous solutions of PAMAM-COOH dendrimers with $\mathrm{Cu}^{2+}$ ions were given in Table 1.

Table 1. Concentrations used to titrate aqueous solutions of PAMAM-COOH dendrimers with $\mathrm{Cu}^{2+}$ ions.

\begin{tabular}{lccc}
\hline Dendrimers & $\begin{array}{c}\text { Dendrimer } \\
\text { Conc. of }\end{array}$ & $\begin{array}{c}\text { Conc. }(\mathbf{m M}) \\
\mathbf{C u S O}_{\mathbf{4}}(\mathbf{m M})\end{array}$ & $\begin{array}{c}\text { Increment } \\
\text { of } \mathbf{C u S O}_{\mathbf{4}}(\boldsymbol{\mu L})\end{array}$ \\
\hline E3.COOH & 0.637 & 80.14 & 44.00 \\
E4.COOH & 0.321 & 80.14 & 44.00 \\
D3.COOH & 0.549 & 79.86 & 44.00 \\
D4.COOH & 0.268 & 80.50 & 44.00 \\
P3.COOH & 0.454 & 79.86 & 55.00 \\
P4.COOH & 0.200 & 79.86 & 52.00 \\
\hline
\end{tabular}

\section{4. Preparation of Cu-DENs Using PAMAM-COOH and PAMAM-TRIS Dendrimer Templates}

Syntheses of $\mathrm{Cu}$-DENs were adapted from the literature. ${ }^{10,26}$ In general, $10.0 \mathrm{~mL}$ of $5.0 \mu \mathrm{M}$ aqueous dendrimer solutions were prepared. This concentration was kept constant for all dendrimer solutions. The $\mathrm{pH}$ of the aqueous dendrimer solution was adjusted to $\mathrm{pH} \sim 8$. Correct amount of aqueous $\mathrm{CuSO}_{4}(\mathrm{pH} \sim 4.62)$ (Table 1) was added to each dendrimer solution. The final $\mathrm{pH}$ of the solu- 
tion was about $\mathrm{pH} \sim 5$. The solution was than stirred for 30 minutes to allow the complexation of $\mathrm{Cu}^{2+}$ ions with the inner tertiary amines of dendrimers. Afterwards, chemical reduction of TRIS and carboxyl terminated $\mathrm{Cu}^{2+}$ loaded $\mathrm{Cu}^{2+} /$ dendrimers with 20 molar excess $\mathrm{NaBH}_{4}$ in $0.10 \mathrm{M} \mathrm{NaOH}$ was resulted in intradendrimer $\mathrm{Cu}$-DENs. Then, $\mathrm{pH}$ was adjusted to $\mathrm{pH} \sim 8$ at where $\mathrm{Cu}$-DENs are most stable ${ }^{26}$ with a negligible amount of dropwise addition of $0.01-0.10 \mathrm{M} \mathrm{HCl}$ and $\mathrm{NaOH}$ solutions. The formation of $\mathrm{Cu}$-DENs was monitored with UV-Vis spectroscopy.

\section{Results and Discussion}

\section{1. Synthesis of PAMAMs}

Microwave-assisted synthesis of PAMAM-TRIS dendrimers with $\mathrm{E}, \mathrm{D}$ and $\mathrm{P}$ core from half generation PAMAM- $\mathrm{OCH}_{3}$ dendrimers, were performed according to our previous studies ${ }^{27}$ and, ${ }^{23}$ respectively. On the other hand, PAMAM-COOH dendrimers were prepared by slight modification of the literature procedure ${ }^{24}$ and our recent study. ${ }^{25}$ The results were in good agreement with the literature. ${ }^{23,27}$ General procedures for the preparation and characterization PAMAM-COOH dendrimers were given in the supplementary material. Molecular weights of the synthesized dendrimers were in the ranges of 2584 and $13647 \mathrm{~g} / \mathrm{mol}$. The prepared dendrimers were stored in methanolic solution and stored at $\pm 4{ }^{\circ} \mathrm{C}$. Some selected properties and characterization data of dendrimers were presented in Table 2.

\section{2. Characterization of PAMAMs}

Synthesized water-soluble dendrimers could easily be characterized via ${ }^{1} \mathrm{H}$ NMR and ${ }^{13} \mathrm{C}$ NMR. Figure 1 show the sample ${ }^{1} \mathrm{H}$ NMR spectrum monitoring of the conversion of D3.5 to D4.COOH, and D4.TRIS. All the expected signals are at the correct intensities and places. The resonances from methyl ester at $3.78 \mathrm{ppm}$ are no longer visible and confirm the complete conversion of the ester groups to acids (D4.COOH, middle in Figure 1) while formation of a new singlet at $3.71 \mathrm{ppm}$, resulting from re-

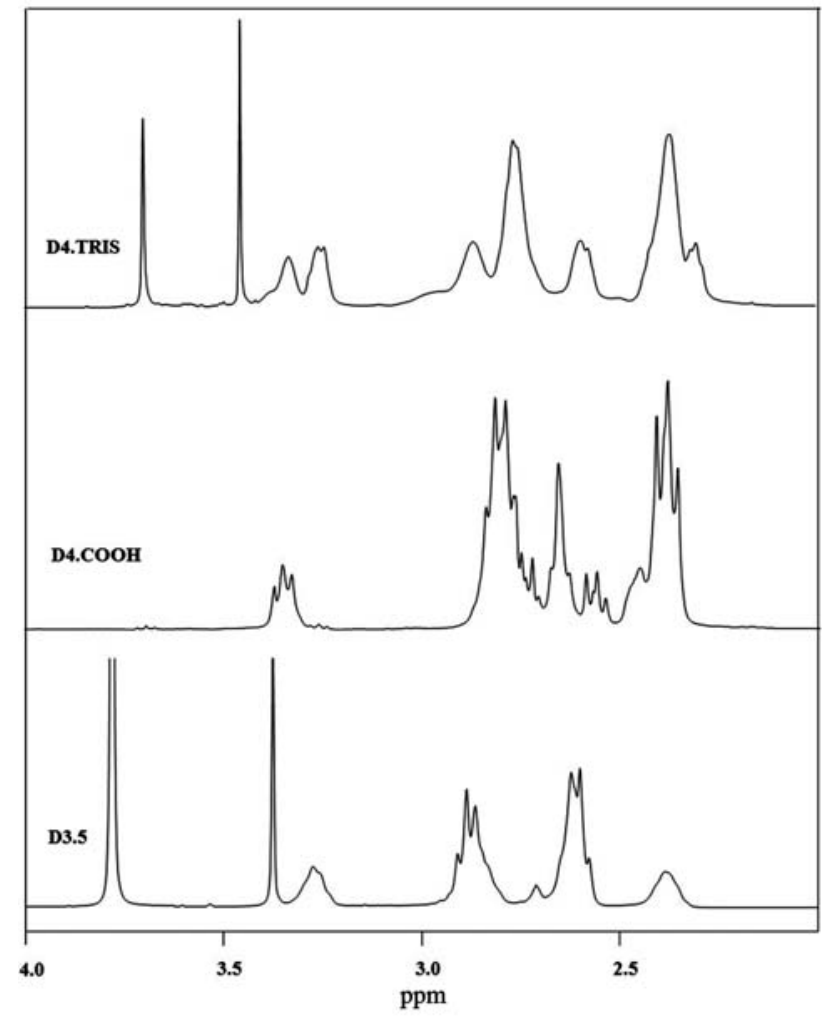

Figure 1. ${ }^{1} \mathrm{H}$ NMR spectrum monitoring of the conversion of D3.5 (bottom) to D4.COOH (middle) and D4.TRIS (Top).

Table 2. The theoretical characteristic data of synthesized PAMAM dendrimers.

\begin{tabular}{|c|c|c|c|c|}
\hline Dendrimer & $\begin{array}{c}\mathbf{M w} \\
(\mathrm{g} / \mathbf{m o l})\end{array}$ & $\begin{array}{c}\text { Number of tertiary } \\
\text { amines }\left(\mathrm{NR}_{3}\right)\end{array}$ & $\begin{array}{c}\text { Number of terminal } \\
\text { hydroxyls }(\mathrm{OH})\end{array}$ & $\begin{array}{c}\text { Number of terminal } \\
\text { carboxyls }(\mathrm{COOH})\end{array}$ \\
\hline \multicolumn{5}{|c|}{$\overline{\text { TRIS-terminated }}{ }^{a}$} \\
\hline E3.TRIS & 4234 & 14 & 48 & - \\
\hline E4.TRIS & 8865 & 30 & 96 & - \\
\hline D3.TRIS & 5230 & 18 & 60 & - \\
\hline D4.TRIS & 11109 & 38 & 120 & - \\
\hline P3.TRIS & 6700 & 21 & 72 & - \\
\hline P4.TRIS & 13647 & 45 & 144 & - \\
\hline \multicolumn{5}{|c|}{ Carboxyl-terminated } \\
\hline E3.COOH & 2584 & 14 & - & 16 \\
\hline E4.COOH & 5564 & 30 & - & 32 \\
\hline D3.COOH & 3258 & 18 & - & 20 \\
\hline D4.COOH & 6983 & 38 & - & 40 \\
\hline P3.COOH & 4226 & 21 & - & 24 \\
\hline $\mathrm{P} 4 . \mathrm{COOH}$ & 8696 & 45 & - & 48 \\
\hline
\end{tabular}

${ }^{\text {a }}$ Data for PAMAM-TRIS dendrimers were taken from the study of Ertürk et al. ${ }^{23}$ 
sonances of new methylene protons adjacent to the terminal hydroxyl groups, indicates full conversion to D4.TRIS (top in Figure 1). Moreover, formation of the 181.61, $181.46,174.86 \mathrm{ppm}$ peaks corresponding to acids and interior amides prove the fully conversion of D3.5 to D4.COOH. Likewise, ${ }^{1} \mathrm{H}$ NMR, the strong resonances corresponding to the methyl groups of terminal methyl group at $173.13(\mathrm{C}=\mathrm{O})$ and $51.87\left(\mathrm{COOCH}_{3}\right) \mathrm{ppm}$ in the ${ }^{13} \mathrm{C}$ NMR are no more available (see supplementary file characterization data). Similar spectral changes were observed during the synthesis of $\mathrm{E}, \mathrm{D}$, and $\mathrm{P}$ cored water-soluble dendrimers.

In ${ }^{13} \mathrm{C}$ NMR of TRIS-terminated conversions, the formation of $56.67\left(\mathrm{NHCR}_{3}\right)$ and $63.6\left(\mathrm{CH}_{2} \mathrm{OH}\right) \mathrm{ppm}$ bands were indicated the fully formation of TRIS-terminated PAMAMs. ${ }^{23}$ Therefore, ${ }^{1} \mathrm{H}$ NMR and ${ }^{13} \mathrm{C}$ NMR spectroscopy evaluations prove a good purity.

In ATR spectroscopy, the disappearance of esteric peak at $1730 \mathrm{~cm}^{-1}$ and formation of two asymmetrical stretching at $1650-1550 \mathrm{~cm}^{-1}$ and a weaker, symmetrical band near $1400 \mathrm{~cm}^{-1}$ also prove the complete conversion of ester terminated D3.5 to D4.COOH (Figure 2). Similar spectral deconvolutions were observed during the synthesis of $\mathrm{E}, \mathrm{D}$, and $\mathrm{P}$ cored water-soluble dendrimers.

\section{3. Spectroscopic Titrations of TRIS and Carboxyl-Terminated PAMAMs}

In order to learn about $\mathrm{Cu}^{2+}$ binding capacity of different generation TRIS and carboxyl-terminated E, D and P cored PAMAMs (Table 2), spectroscopic titration studies were performed. Figure 3 shows the sample spectros- copic titration spectra of carboxyl-terminated E4.COOH, $\mathrm{D} 4 . \mathrm{COOH}$, and $\mathrm{P} 4 . \mathrm{COOH}$ dendrimers. Investigation of the Figure 3 reveals that absorbances of $\mathrm{Cu}^{2+} / \mathrm{DEN}$ complexes increases with the addition of the increasing amount of $\mathrm{Cu}^{2+}$.

In their former studies, Crooks et al. ${ }^{10,26}$ declared that the number of tertiary amines are important to determine the exact number of the maximum metal loading capacity of PAMAMs. In our intra-dendrimer complexation studies, we have observed a sudden deep-blue color change with the addition $\mathrm{Cu}^{2+}$ ions over PAMAM-TRIS and PAMAM-COOH dendrimer solutions. We have characterized this color change by UV-Vis spectroscopy, and observed a common broad absorption band at $\lambda \max =$ $680 \mathrm{~nm}$ for E, D, and P cored PAMAM-TRIS and PAMAM-COOH dendrimers (Figure 3$)$. This band $(d-d$ transition) indicates the formation of tetradentate (1:4 dendrimer to tertiary amine molar ratio) complexes between the tertiary amine groups of PAMAMs and $\mathrm{Cu}^{2+}$ ions. $^{23,28}$

Figure 4 shows the spectroscopic titration curves of E4.COOH, D4.COOH and P4.COOH dendrimers with $\mathrm{Cu}^{2+}$ ions. The experimental end points derived from these curves were presented in Table 3 regarding absorbance at $\lambda \max =680 \mathrm{~nm}$ versus $\mathrm{Cu}^{2+} / \mathrm{DENs}$ molar ratio plots. Indeed, maximum molar excess of $\mathrm{Cu}^{2+}$ ions that can be loaded to dendrimers were calculated from these plots. Results showed that PAMAM-COOH dendrimers used in this study absorb the number of $\mathrm{Cu}^{2+}$ ions equivalent the number of tertiary amine numbers, and the structure of these dendrimers are at the desired monodipersity similar to those of PAMAM-TRIS dendrimers, we reported in our recent study. ${ }^{23}$

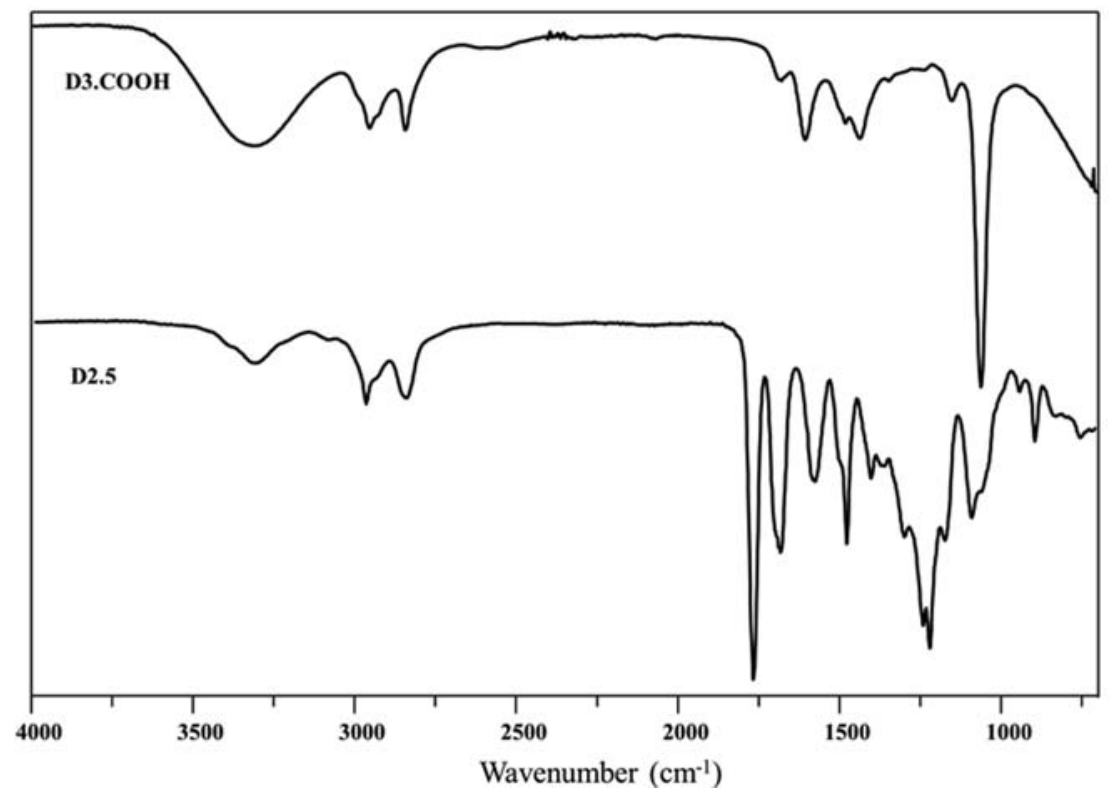

Figure 2. ATR monitoring and time dependency from ester to amide (D2.5 to D3.COOH). 

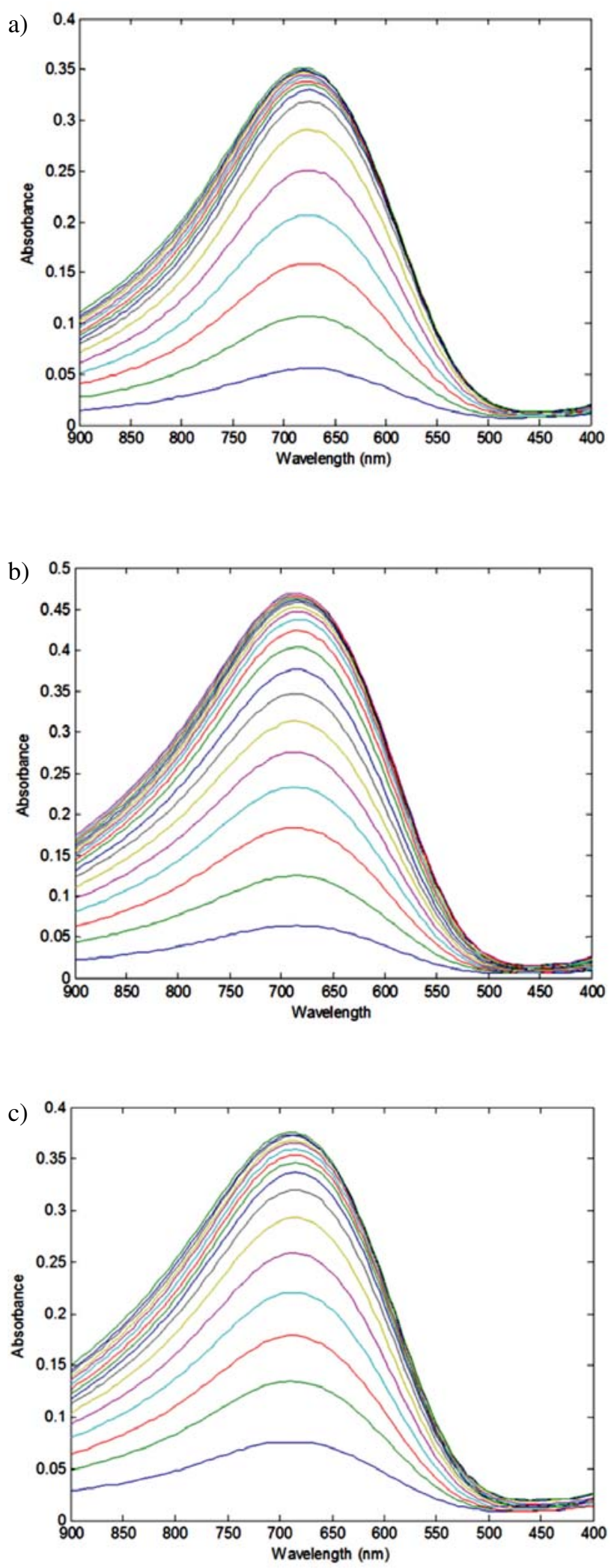

Figure 3. Absorption spectra (at $680 \mathrm{~nm}$ ) of (a) E4.COOH dendrimer $(0.321 \mathrm{mM})$ solution titrated with $\mathrm{Cu}^{2+}(80.14 \mathrm{mM})$, (b) D4.COOH dendrimer $(0.268 \mathrm{mM})$ solution titrated with $\mathrm{Cu}^{2+}$ $(80.50 \mathrm{mM})$, (c) P4.COOH dendrimer $(0.200 \mathrm{mM})$ solution titrated with $\mathrm{Cu}^{2+}(79.86 \mathrm{mM})$.
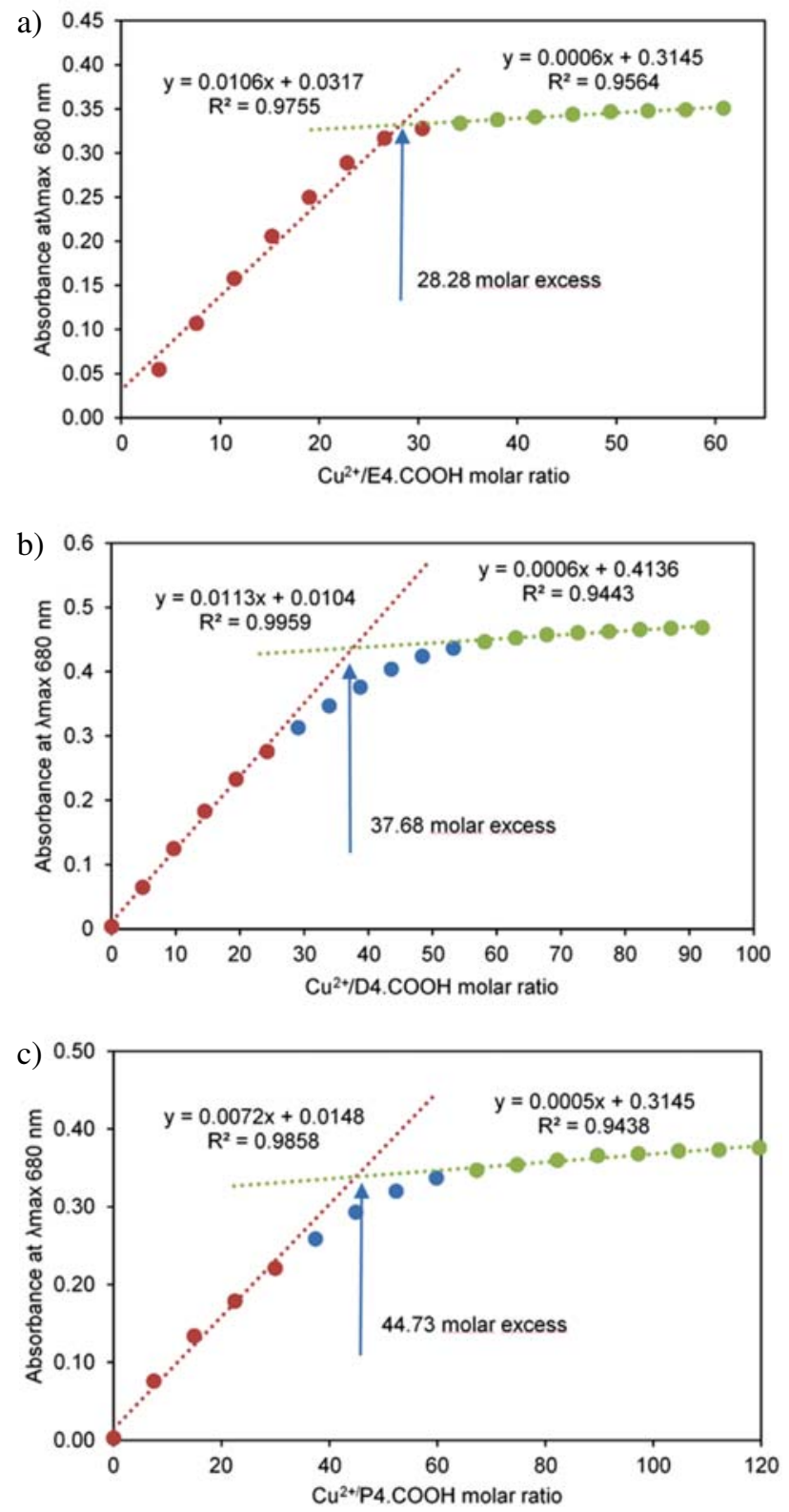

Figure 4. Spectroscopic titration curve of (a) E4.COOH; (b) D4.COOH; (c) P4.COOH with $\mathrm{Cu}^{2+}$ ions at $\lambda \max =680 \mathrm{~nm}$.

Table 3. Number of amine groups on carboxyl-terminated PAMAMs available for binding with $\mathrm{Cu}^{2+}$ ions.

\begin{tabular}{lcc}
\hline Dendrimer & $\begin{array}{c}\text { Calculated } \\
\text { end point }\end{array}$ & $\begin{array}{c}\text { Experimentally } \\
\text { obtained end point }\end{array}$ \\
\hline E3.COOH & 14 & 14.00 \\
E4.COOH & 30 & 28.28 \\
D3.COOH & 18 & 17.80 \\
D4.COOH & 38 & 37.68 \\
P3.COOH & 21 & 20.59 \\
P4.COOH & 45 & 44.73 \\
\hline
\end{tabular}

${ }^{a}$ Each end point has been calculated as an average value of three experimental runs and see for the experimental values of PAMAMTRIS dendrimers. ${ }^{23}$ 


\section{4. Synthesis and UV-Vis Characterization of Cu-DENs}

Most common procedure for the synthesis of DENs involves first the determination of the appropriate number of metal ion ratio to be complexed with dendrimer solutions under $\mathrm{pH}$ control, and then this is followed by the reduction of metal ions inside the dendrimer by an appropriate reducing agent. ${ }^{10}$ Sodium borohydride $\left(\mathrm{NaBH}_{4}\right)$ is used as the reducing agent. Appropriate chemical excess of $\mathrm{NaBH}_{4}$ leads to zerovalent intradendrimer metal nanoparticles. Immediate change in metal ion dendrimer aqueous solution color indicates the reduction. In the case of $\mathrm{Cu}, \mathrm{LMCT}$ peak at around $300 \mathrm{~nm}$ arising from $\mathrm{Cu}-\mathrm{DEN}$ $\mathrm{s}$ are replaced with a monotically increasing absorbance band toward shorter wavelength. This indicates the formation of small nanoparticles. In addition, an absence of plasman peak at around $570-590 \mathrm{~nm}$ proves that $\mathrm{Cu}$ clusters are smaller than $4 \mathrm{~nm} .{ }^{29,30}$ Transition $\mathrm{d}$-d complex band resulting from the coordination of internal amine groups of ethanol amine-terminated PAMAMs were reported at $\lambda \max$ at $605 \mathrm{~nm} .{ }^{10}$ This band reported in the range of $600-800 \mathrm{~nm}$ depending on surface modification with TRIS. ${ }^{28}$
Syntheses of Cu-DENs were adapted from the literature. ${ }^{10,26}$ After the number of $\mathrm{Cu}^{2+}$ ions that can be loaded to E, D and P cored PAMAM-TRIS dendrimers were determined from binding studies reported in our recent study ${ }^{23}$ similar synthetic procedures were applied for the synthesis $\mathrm{Cu}(\mathrm{II})$ intra-dendrimer complexes of $\mathrm{E}, \mathrm{D}$, and $\mathrm{P}$ cored PAMAM-COOH dendrimers.

A straightforward evidence for the reduction of $\mathrm{Cu}^{2+}$ ions into dendrimer cavity comes from the immediate change in solution color from blue to golden brown as being parallel to literature ${ }^{10,26}$ (Figure 6). Upon the addition of appropriate molar ratio of calculated $\mathrm{CuSO}_{4}$ solutions to the aqueous dendrimer solutions, strong bands at around 270-280 nm for carboxyl (Figure 7) and 280-300 $\mathrm{nm}$ for TRIS-terminated (Figure 8) PAMAMs were occurred, respectively. These bands are assigned to LMCT bands. ${ }^{31-33}$ In addition, $d-d$ copper transition band at around $680 \mathrm{~nm}$ for all $\mathrm{Cu}^{2+} / \mathrm{DEN}$ complex solutions were observed (Figure 7,8). This band could not be observable for low concentrations. After the addition of excess reducing agent $\mathrm{NaBH}_{4}, \mathrm{LMCT}$ peak at around $300 \mathrm{~nm}$ and $d-d$ transition band at $680 \mathrm{~nm}$ in all $\mathrm{Cu}^{2+} / \mathrm{DENs}$ were immediately disappeared and replaced with a nearly exponen-

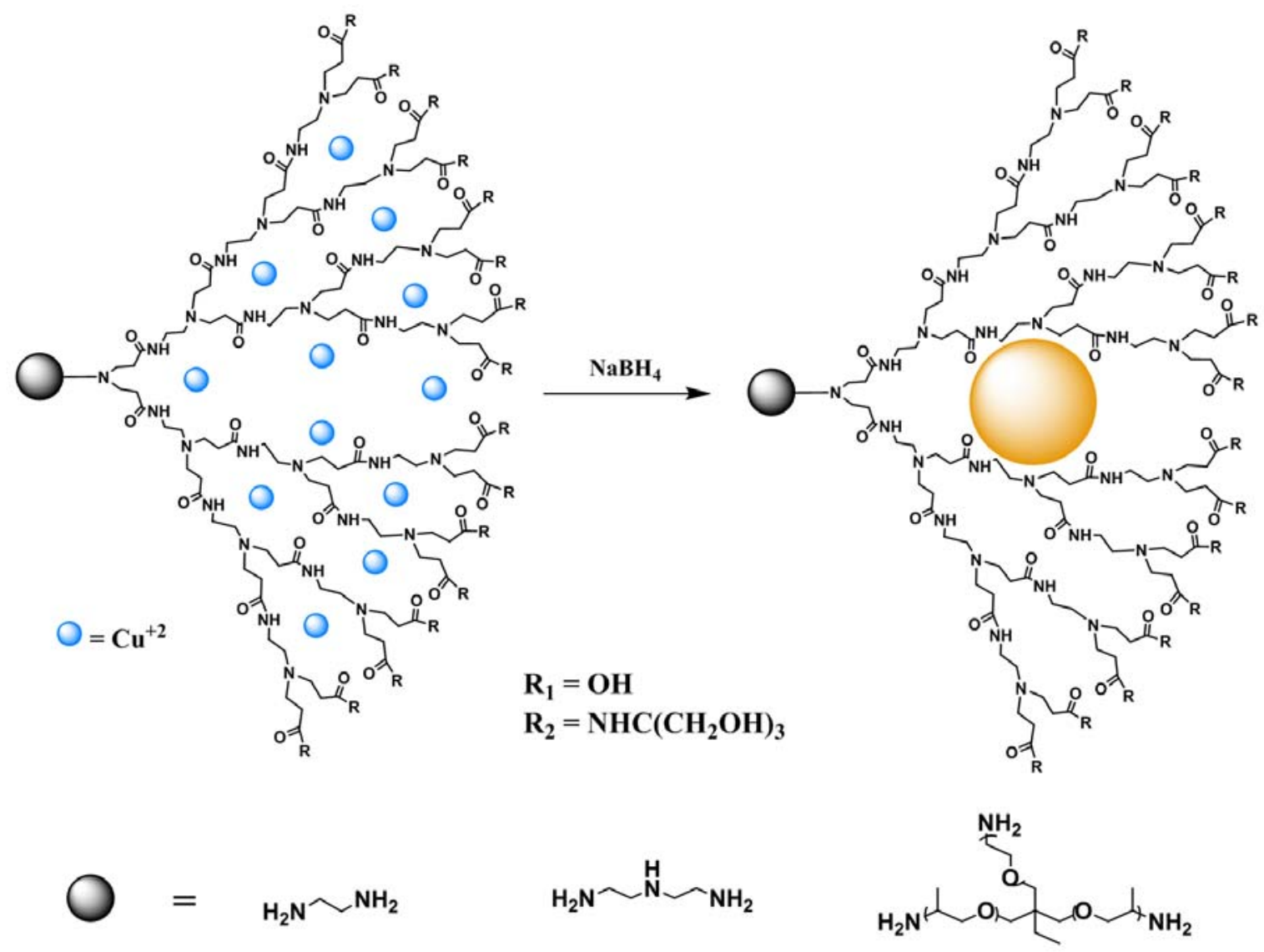

Dendrimer core Ethylenediamine (E) Diethylene triamine (D) Jeffamine ${ }^{\circledR} \quad$ T-403 (P)

Figure 5. Synthetic route for E, D and P core PAMAM-COOH and PAMAM-TRIS Cu-DENs. 
a)

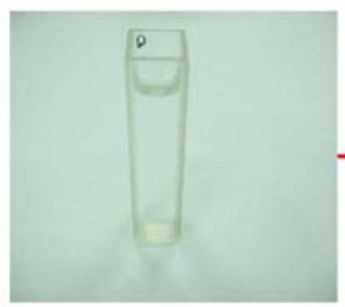

Dendrimer solutions b)

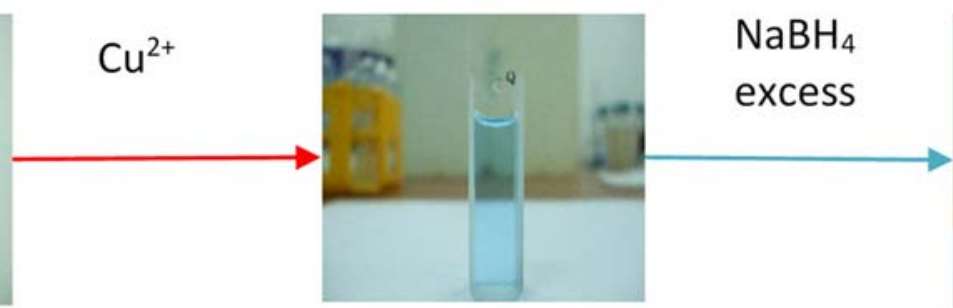

$\mathrm{Cu}^{2+}$ dendrimer complex c)

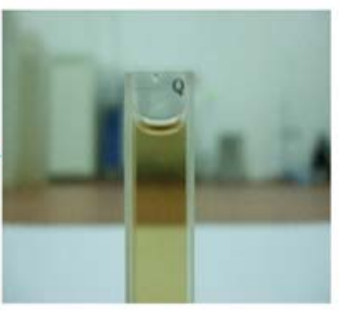

CU-DENS

Figure 6. Change in color during the synthesis of Cu-DENs. (a) aqueous dendrimer solutions, (b) $\mathrm{Cu}^{2+}$ dendrimer complex solution, (c) $\mathrm{Cu}-\mathrm{DENs}$ solution.

a)

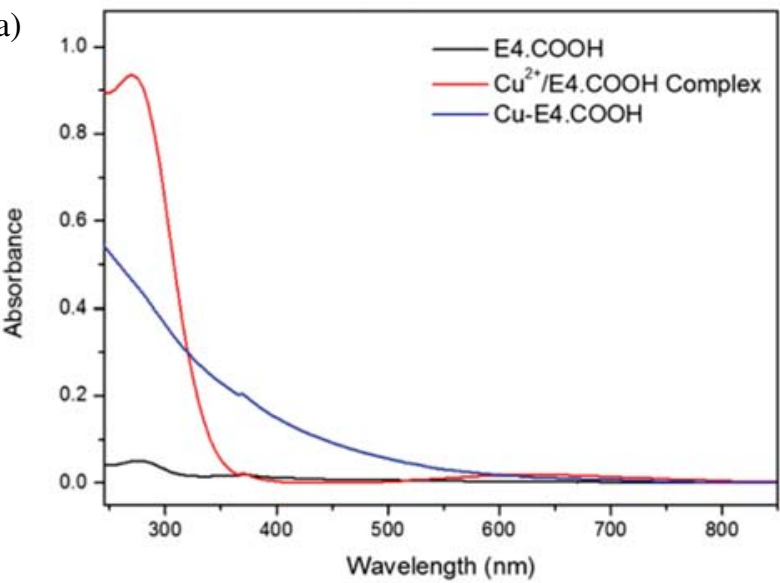

b)

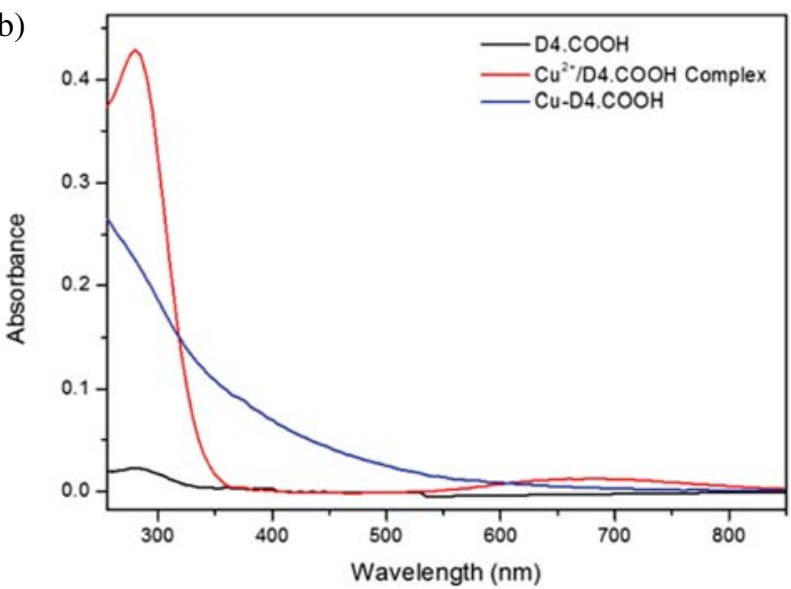

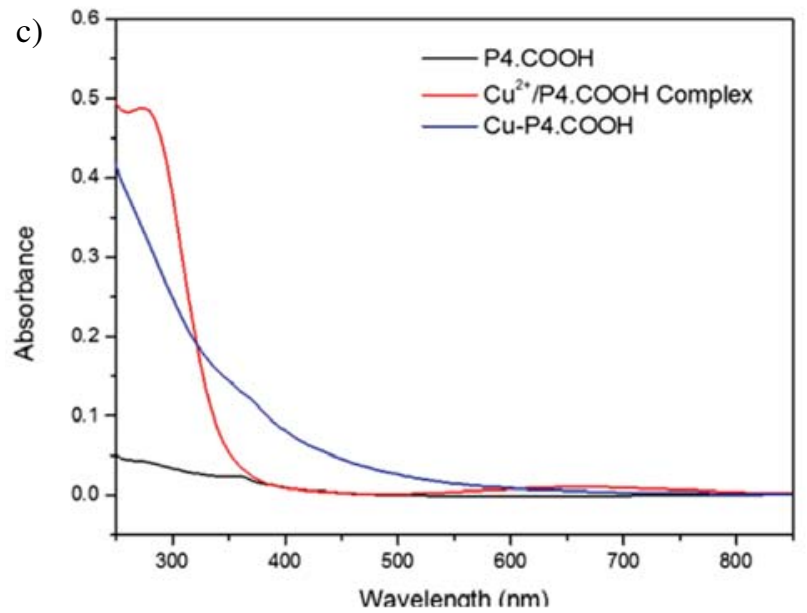

Figure 7. UV-Vis absorption spectra of the formation of (a) $\mathrm{Cu}-\mathrm{E} 4 . \mathrm{COOH}$; (b) $\mathrm{Cu}-\mathrm{D} 4 . \mathrm{COOH}$, and (c) $\mathrm{Cu}-\mathrm{P} 4 . \mathrm{COOH}$.

tial monotically increasing spectrum towards to shorter wavelengths (Figure 7, 8). Moreover, the size of $\mathrm{Cu}$ clusters can be understood from the absence of a Mie plasman peak at around $570 \mathrm{~nm}$ in UV-Vis spectra (Figure 8).
The absence of this band indicates that $\mathrm{Cu}$ clusters within the dendrimer cavity are smaller than $5 \mathrm{~nm} .{ }^{10}$ Results of the UV characterizations are in good agreement with the previously reported $\mathrm{Cu}-\mathrm{DENs} .^{10,26}$ 

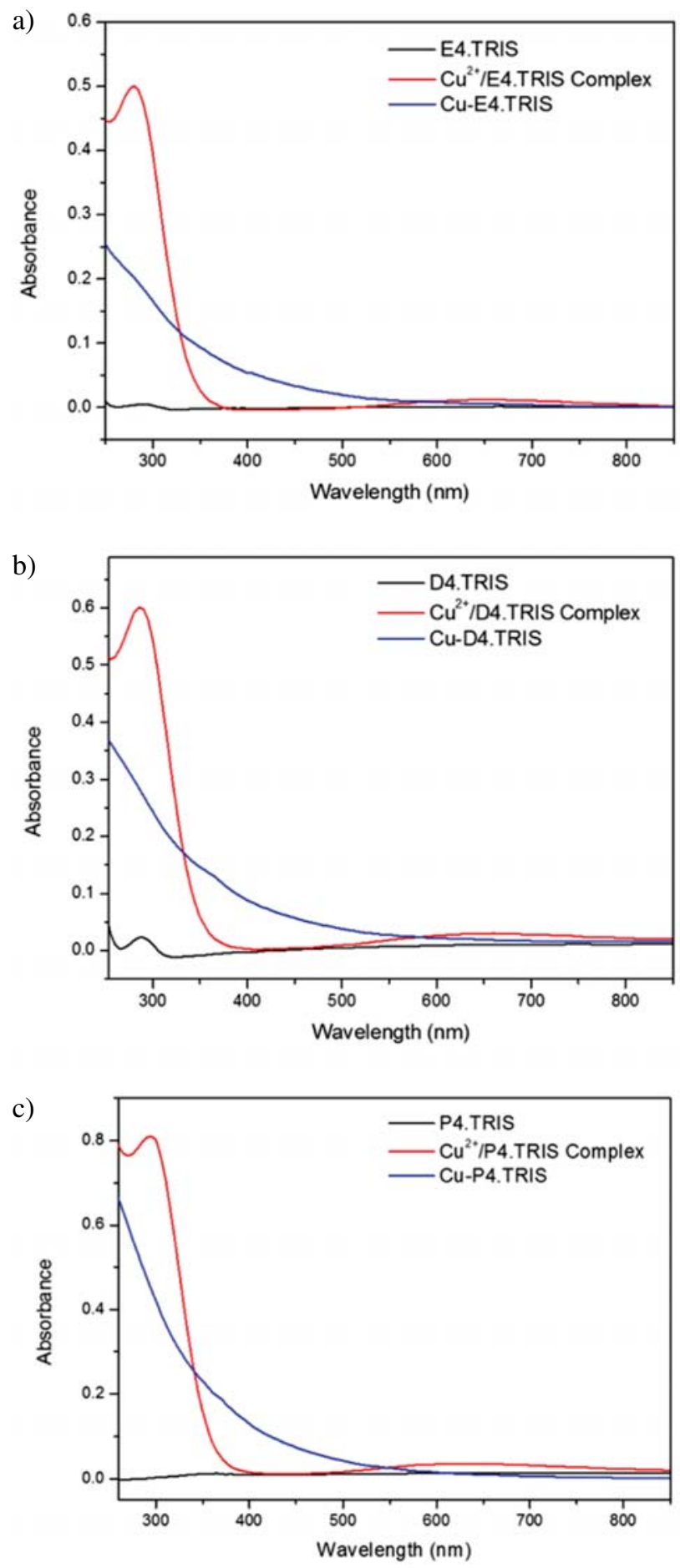

Figure 8. UV-Vis absorption spectra of the formation of (a) $\mathrm{Cu}$ E4.TRIS; (b) Cu-D4.TRIS, and (c) Cu-P4.TRIS.

\section{Conclusions}

In this study, TRIS and Carboxyl surface modified E, D and P cored G3-G4 PAMAM dendrimers were synthesized as macromolecular templates, and used in the synthesis of Cu-DENs. In particular, G3 and G4, D and P cored PAMAM-COOH dendrimer templates, and Cu-PAMAM-TRIS and $\mathrm{Cu}$-PAMAM-COOH nanocomposites were prepared and characterized for the first time.

Investigations of the maximum metal loading capacity of PAMAM-TRIS and PAMAM-COOH dendrimers were determined by the spectroscopic titrations with $\mathrm{Cu}^{2+}$ ions and optimum molar ratios were calculated. The most sparingly evidence of the successfully synthesis of $\mathrm{Cu}-$ DENs came from the color change from blue to golden brown. UV-Vis evidence of this color change was the disappearance of $\mathrm{d}-\mathrm{d}$ complexation band at $\sim 680 \mathrm{~nm}$ and formation of monotically increasing exponential absorption band towards to low wavelengths. The size of $\mathrm{Cu}$ clusters can be understood from the absence of a Mie plasmon peak at around $570 \mathrm{~nm}$ in UV-Vis spectra. The absence of this band indicates that $\mathrm{Cu}$ clusters are smaller than $5 \mathrm{~nm} .{ }^{10}$ All of these observations indicated the succesfull synthesis of $\mathrm{Cu}$-DENs. Catalytic properties of these novel series of $\mathrm{Cu}$-DENs might be interesting for catalytic evaluation in organic synthesis, and in a wide range of future studies.

\section{Acknowledgement}

This research has been supported by Yýldýz Technical University Scientific Research Projects Coordination Department, Project Numbers (2011-01-02-KAP04, 2011-01- 02-KAP05, 2011-01-02-KAP06 and 2012-0102-DOP05). The authors declare that there is no conflict of interest or competing financial interest related to the work described.

\section{References}

1. M. Fischer and F. Vögtle, Angew. Chem., Int. Ed. 1999, 38, 884-905.

http://dx.doi.org/10.1002/(SICI)1521-3773(19990401)

38:7<884::AID-ANIE884>3.0.CO;2-K

2. S. M. Cohen, S. Petoud and K. N. Raymond, Chem. - Eur. J. 2001, 7, 272-279.

http://dx.doi.org/10.1002/1521-3765(20010105)7:1<272:: AID-CHEM272>3.0.CO;2-Y

3. R. W. J. Scott, O. M. Wilson and R. M. Crooks, J. Phys. Chem. B 2004, 109, 692-704.

http://dx.doi.org/10.1021/jp0469665

4. R. M. Crooks, M. Zhao, L. Sun, V. Chechik and L. K. Yeung, Acc. Chem. Res. 2001, 34, 181-190. http://dx.doi.org/10.1021/ar000110a

5. C. Valério, E. Alonso, J. Ruiz, J.-C. Blais and D. Astruc, Angew. Chem., Int. Ed. 1999, 38, 1747-1751. http://dx.doi.org/10.1002/(SICI)1521-3773(19990614) 38:12<1747::AID-ANIE1747>3.0.CO;2-G

6. J. W. J. Knapen, d. M. A. W. van, W. J. C. de, L. P. W. N. M. van, P. Wijkens, D. M. Grove and K. G. van, Nature (Lon- 
don) 1994, 372, 659-63. http://dx.doi.org/10.1038/372659a0

7. D. A. Tomalia and P. R. Dvornic, Nature (London) 1994, 372, 617-8. http://dx.doi.org/10.1038/372617a0

8. A. P. Alivisatos, Science 1996, 271, 933-937. http://dx.doi.org/10.1126/science.271.5251.933

9. L. Balogh and D. A. Tomalia, J. Am. Chem. Soc. 1998, 120, 7355-7356. http://dx.doi.org/10.1021/ja980861w

10. M. Zhao, L. Sun and R. M. Crooks, J. Am. Chem. Soc. 1998, 120, 4877-4878. http://dx.doi.org/10.1021/ja980438n

11. K. Esumi, A. Suzuki, A. Yamahira and K. Torigoe, Langmuir 2000, 16, 2604-2608. http://dx.doi.org/10.1021/la991291w

12. F. Gröhn, B. J. Bauer, Y. A. Akpalu, C. L. Jackson and E. J. Amis, Macromolecules 2000, 33, 6042-6050. http://dx.doi.org/10.1021/ma000149v

13. J. Zheng and R. M. Dickson, J. Am. Chem. Soc. 2002, 124, 13982-13983. http://dx.doi.org/10.1021/ja0282821

14. M. F. Ottaviani, F. Montalti, M. Romanelli, N. J. Turro and D. A. Tomalia, J. Phys. Chem. C 1996, 100, 11033-11042. http://dx.doi.org/10.1021/jp953261h

15. M. Zhao and R. M. Crooks, Chem. Mater. 1999, 11, 33793385. http://dx.doi.org/10.1021/cm990435p

16. R. M. Crooks, M. Zhao, L. Sun, V. Chechik and L. K. Yeung, Accounts Chem. Res. 2000, 34, 181-190. http://dx.doi.org/10.1021/ar000110a

17. A. Okugaichi, K. Torigoe, T. Yoshimura and K. Esumi, Colloids Surf., A 2006, 273, 154-160. http://dx.doi.org/10.1016/j.colsurfa.2005.08.028

18. M. Zhao and R. M. Crooks, Advanced Materýals-Deerfýeld Beach- 1999, 11, 217-220.

http://dx.doi.org/10.1002/(SICI)1521-4095(199903)11:3 $<217:$ :AID-ADMA217>3.0.CO;2-7

19. M. S. Diallo, S. Christie, P. Swaminathan, J. H. Johnson and W. A. Goddard, Environ. Sci. Technol. 2005, 39, 1366-1377. http://dx.doi.org/10.1021/es048961r

20. H. Wan, S. Li, T. A. Konovalova, S. F. Shuler, D. A. Dixon and S. C. Street, J. Phys. Chem. C 2008, 112, 1335-1344. http://dx.doi.org/10.1021/jp075780d

21. E. Vasile, A. Serafim, D. Petre, D. Giol, P. Dubruel, H. Iovu and I. Stancu, The Scientific World Journal 2014, 2014.

22. A. E. Beezer, A. S. H. King, I. K. Martin, J. C. Mitchell, L. J. Twyman and C. F. Wain, Tetrahedron 2003, 59, 3873-3880. http://dx.doi.org/10.1016/S0040-4020(03)00437-X

23. A. S. Erturk, M. U. Gurbuz, M. Tulu and A. E. Bozdogan, RSC Adv. 2015, 5, 60581-60595.

24. R. Yin, Y. Zhu, D. Tomalia and H. Ibuki, J. Am. Chem. Soc. 1998, 120, 2678-2679. http://dx.doi.org/10.1021/ja973972o

25. K. Öztürk, A. S. Ertürk, C. Sarýsözen, M. Tulu and S. Çalis, J. Microencapsulation, 0, 1-10.

26. Z. V. Feng, J. L. Lyon, J. S. Croley, R. M. Crooks, D. A. Vanden Bout and K. J. Stevenson, J. Chem. Educ. 2009, 86, 368. http://dx.doi.org/10.1021/ed086p368

27. A. S. Ertürk, M. Tülü, A. E. Bozdoğan and T. Parali, Eur. Polym. J. 2014, 52, 218-226. http://dx.doi.org/10.1016/j.eurpolymj.2013.12.018

28. P. Chen, Y. Yang, P. Bhattacharya, P. Wang and P. C. Ke, The Journal of Physical Chemistry C 2011, 115, 12789-12796. http://dx.doi.org/10.1021/jp202417w

29. A. C. Curtis, D. G. Duff, P. P. Edwards, D. A. Jefferson, B. F. G. Johnson, A. I. Kirkland and A. S. Wallace, Angew. Chem., Int. Ed. Engl. 1988, 27, 1530-1533. http://dx.doi.org/10.1002/anie.198815301

30. I. Lisiecki and M. P. Pileni, J. Am. Chem. Soc. 1993, 115, 3887-3896. http://dx.doi.org/10.1021/ja00063a006

31. H. Yokoi and T. Isobe, Bull. Chem. Soc. Jpn. 1969, 42, 2187-2193. http://dx.doi.org/10.1246/bcsj.42.2187

32. B. P. Kennedy and A. B. P. Lever, J. Am. Chem. Soc. 1973, 95, 6907-6913. http://dx.doi.org/10.1021/ja00802a006

33. A. R. Amundsen, J. Whelan and B. Bosnich, J. Am. Chem. Soc. 1977, 99, 6730-6739.

http://dx.doi.org/10.1021/ja00462a042

\section{Povzetek}

V prispevku je predstavljena sinteza in UV-Vis karakterizacija Cu nanokompozitov iz etilendiamina (EDA) (E), dietilentriamina (DETA) (D) in Jeffamine ${ }^{\circledR}$ T-403 (P) PAMAM (poli(amidoamin)) dendrimerov s TRIS (tris(hidroksimetil)aminometan) in karboksilnimi funkcionalnimi skupinami na površini. Cu-PAMAM dendrimere $\mathrm{z}$ enkapsuliranimi nanodelci (Cu-DENs) smo karakterizirali z UV-Vis spektroskopijo. Kot dokaz za uspešno sintezo Cu-DENs nanokompozitov lahko navedemo izginotje vrhov pri $680 \mathrm{~nm}$ (d-d prenos) in 270-300 nm (prenos naboja med ligandom in kovino (LMCT)) in formiranje eksponentnega pasu. Dodaten dokaz uspešne sinteze je tudi takojšnja sprememba barve raztopine dendrimer-kovina iz modre $\mathrm{v}$ zlato rjavo, ki je posledica redukcije $\mathrm{Cu}^{2+}$ ionov. Tako pripravljene $\mathrm{Cu}-\mathrm{DENs}$ nanokompozite bi bilo mogoče uporabiti kot novo alternativo obstoječim nanomaterialom, ki se uporabljajo v številnih aplikacijah: biološki in kemični senzorji, kataliza, hidrogenacija, oksidacija, polprevodniki, plemenite kovine, magnetni dendrimerni nanokompoziti, okoljska problematika in mnoge druge. 